\title{
Research and Application of Hydraulic Injection Precise Fracturing Technology in W27 Oilfield
}

\author{
Yang Li-yong ${ }^{*}$,Yin Shun-li,Zhuang Tian-lin,Gou Xiao-ting,Du Yu-qiao \\ PetroChina Dagang Oilfield Company, Tianjin, 300280, China
}

\begin{abstract}
W27 oilfield is a multi-layer heterogeneous low permeability reservoir, which has entered the middle and late stage of development. The main reservoir is flooded seriously, and the remaining oil distribution is complex. If conventional fracturing technology is adopted, the risk of longitudinal fracture communication with water layer or water-flooded layer is high, which is easy to cause high water cut after fracturing and affect the fracturing effect. According to the characteristics of fractured well reservoir, the hydraulic injection fracturing technology is optimized to optimize the position of injection point and fracturing process parameters, avoid pressing water layer, and achieve accurate reconstruction of potential reservoir. The technology was applied to 4 Wells on site, and the average daily oil gain per well was 6 tons and the average accumulated oil gain per well was 2,500 tons. Hydraulic injection precision fracturing technology has an obvious effect on water control and oil increase in W27 oilfield, which has an important guiding significance for similar reservoirs to improve the fracturing effect.
\end{abstract}

\section{Basic situation}

\subsection{The development situation}

W27 Oilfield was officially put into development in December 1992. The buried depth of the reservoir is $2,866-3,125 \mathrm{~m}$, the average porosity is $17 \%$, and the average permeability is $63 \times 10^{-3} \mathrm{um}^{2}$. It belongs to the middle and low porosity and low permeability reservoir. The recoverable reserves of the block are 1.28 million tons. At present, the total recoverable reserves are 990,000 tons and the remaining 290,000 tons. The remaining recoverable reserves are rich. In order to improve the development effect of the block, it is necessary to carry out fracturing measures to improve the seepage environment near the well and increase the production of single well.

W27 Oilfield has entered the stage of high water cut at present, which belongs to the middle and late stage of development. Although the remaining recoverable reserves are abundant, the main dominant reservoirs are flooded seriously, some thin and poor reservoirs and those with relatively poor connectivity are put into low use, and the remaining oil is highly dispersed, making it difficult to tap potential(Fig.1).

In order to improve the utilization degree of remaining oil in the block, four Wells were selected in this block, and the hydraulic jet fixed-point fracturing technology was researched and tested.

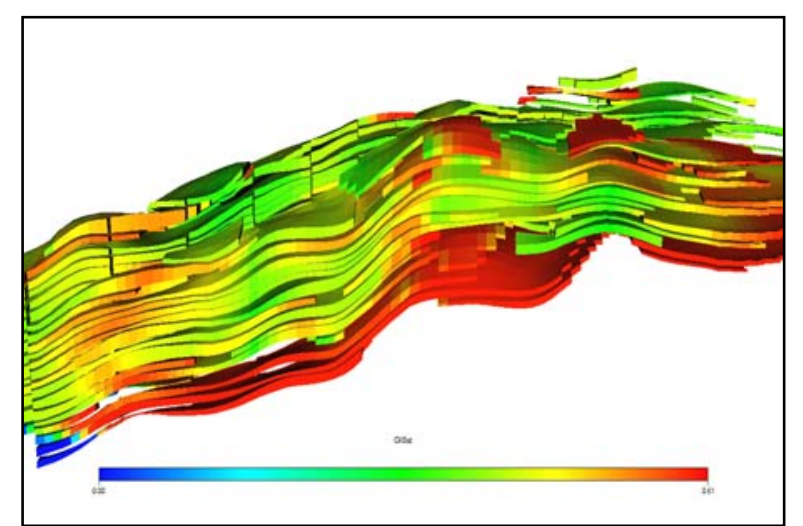

Fig. 1. Distribution diagram of remaining oil in W27 Oilfield.

\subsection{Analysis of fracturing difficulties}

The fractured target layer of G83-44 is $3021-3082.9 \mathrm{~m}$, the top is $3 \mathrm{~m}$ from the water layer, the bottom is $1.5 \mathrm{~m}$ from the water layer, and there is a water-flooded layer in the middle of the target layer (Fig.2). If conventional fracturing is used, the fracture initiation point is not controllable, and the risk of longitudinal fracture communication with water layer is large, which is easy to cause water outlet after pressure and affect the fracturing effect. Well G83-44 was conventional fractured and propped to a top of 3,015 $\mathrm{m}$ and a bottom of 3,092 $\mathrm{m}$, connecting the top and bottom water layers with the middle flooded layer (Fig.3).

\footnotetext{
* Introduction:Yang Li-yong(1987-),Male, Master degree, Engineer,Mainly engaged in fracturing technology research.Company:Petroleum Engineering Research Institute of Dagang Oilfield, PetroChina.Tel:022-

25925802.Mobile:18730773201.E-mail:yanglyong@petrochina.com.cn.Address:Petroleum Engineering Research Institute, Dagang Oilfield, Binhai New Area, Tianjin, China
} 

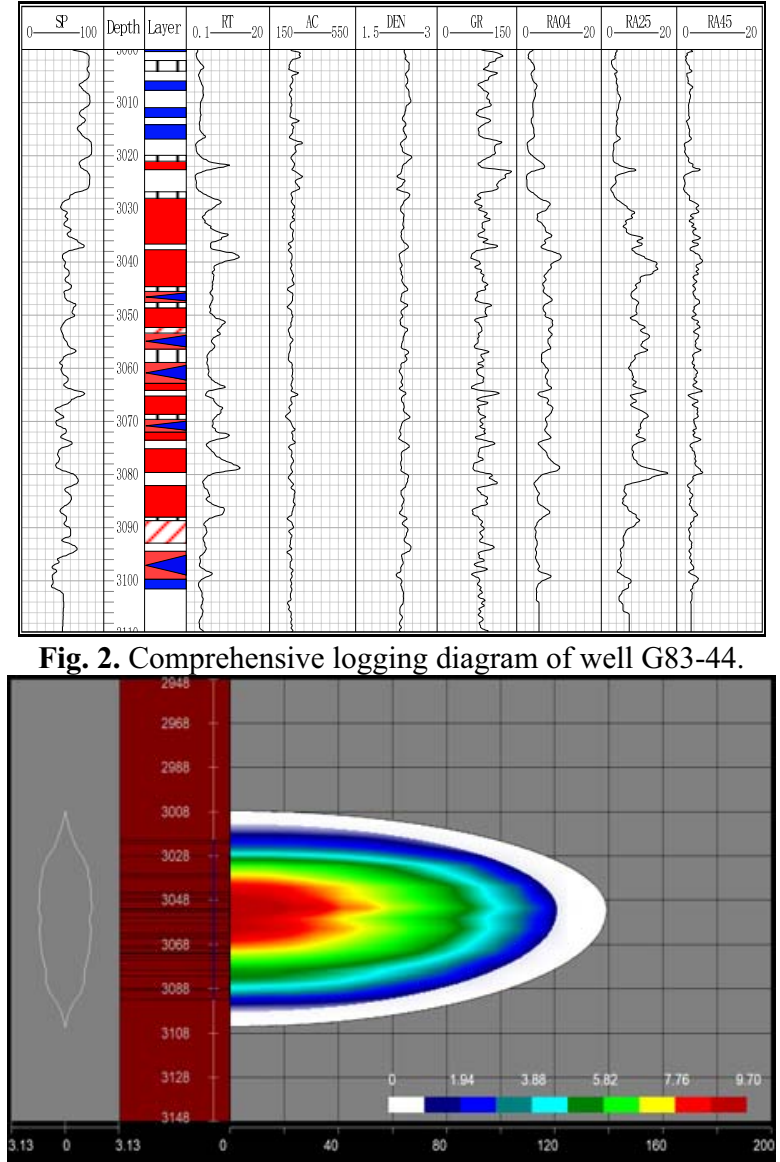

Fig. 3. Simulated fracture profile of well G83-44.

\section{Fracturing process optimization}

\subsection{Fracturing process optimization}

Hydraulic jet fracturing technology is the frontier technology and development direction of hydraulic fracturing. It integrates hydraulic perforation, fracturing and isolation, which is a new stimulation measure. Hydraulic jetting has the advantages of creating fractures accurately in a given location, eliminating the need for mechanical isolation, reducing operational risk and reducing operational time ${ }^{[1]}$.

In view of the reservoir characteristics and transformation difficulties of the target formation of well G83-44, the hydraulic jet fracturing technology is selected to form fractures in the designated position to avoid pressing the layer of boiling water and improve the fracturing effect ${ }^{[2]}$.

\subsection{Injection point optimization}

The fracture section of well G83-44 is $3021-3092.9 \mathrm{~m}$, with a total of $49.4 \mathrm{~m} / 6$ layers. According to the comprehensive logging curve and reservoir physical properties of the well, the optimized injection fracturing points are $3039.0 \mathrm{~m}$ and $3078.0 \mathrm{~m}$ (Fig.4).

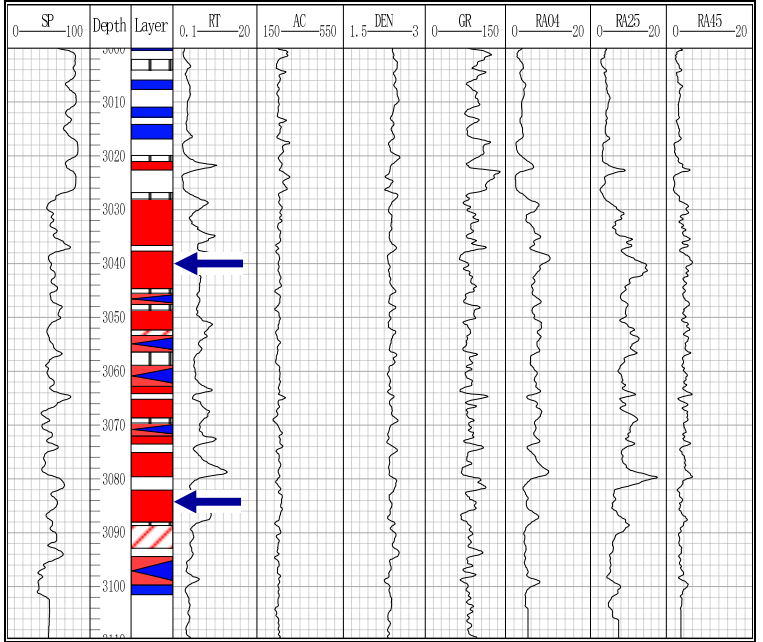

Fig. 4. Comprehensive logging diagram of well G83-44.

\section{Optimization of fracturing process parameters}

\subsection{Prediction of wellhead oil pressure and casing pressure}

According to the principle of hydraulic jet, the conditions for the formation to be successfully pressed open $\operatorname{are}^{[3]}$.

$$
P_{\mathrm{a}}+P_{\mathrm{h}}+P_{b}-\Delta P_{2} \geq P_{f a c}
$$

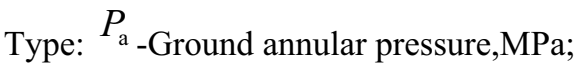

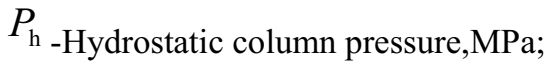

$P_{b}$-Pressurization value in perforation holes, $\mathrm{MPa}$;

$P_{f a c}$-Formation rupture pressure, $\mathrm{MPa}$;

The pressurization value in the perforation hole is determined according to the nozzle pressure drop.According to the field construction data,the general nozzle pressure drop of $30 \mathrm{MPa}$ can ensure the success of fracturing.According to the laboratory experimental data and numerical simulation, when the nozzle pressure drop is $30 \mathrm{MPa}$, the pressurization in the hole is about 6.0 $\mathrm{MPa}^{[4]}$.

\subsubsection{The relationship between nozzle pressure drop and displacement ${ }^{[5]}$}

Nozzle flow loss equation.

$$
\Delta p=22.45 \rho \frac{Q^{2}}{n^{2} d^{2} C_{d}^{2}}
$$

Type: $\Delta p$-Nozzle hole pressure difference,MPa;

$Q_{\text {-Injection capacity, } \mathrm{m}^{3} / \mathrm{min} \text {; }}$

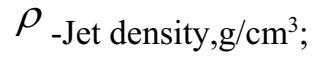

$C_{\mathrm{d}}$-Hole flow coefficient (usually 0.8-

1.0),dimensionless;

$d$-The nozzle diameter; 
$n$-Nozzle hole number.

\subsubsection{Equivalent diameter of nozzle is calculated}

If the displacement and pressure drop of the nozzle are known, it is necessary to calculate the equivalent diameter of the nozzle first in order to obtain the jet velocity, as shown in Equation ${ }^{[6]}$.

$$
d e=\left[\frac{0.82 \times 10^{-7} \rho Q^{2}}{c^{2} \Delta p}\right]^{\frac{1}{4}}
$$

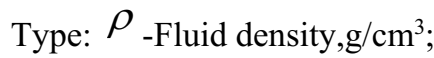

$d e$-Equivalent diameter of nozzle,cm.

If $\mathrm{n}$ nozzles with equal diameter are evenly distributed on the nozzle, then the diameter of each nozzle is ${ }^{[7]}$.

$$
d=\frac{d e}{\sqrt{n}}
$$

Jet velocity of nozzle.

$$
v_{0}=\frac{Q}{15 n \pi d^{2}} \times 10^{6}
$$

Type: $n$-The nozzle hole number;

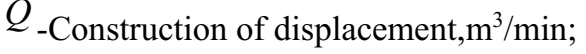

$v_{0}$-The injection speed, $\mathrm{m} / \mathrm{s}$;

$D$-The nozzle diameter, $\mathrm{mm}$.

\subsubsection{Prediction of oil pressure and casing pressure in G83-44 well}

The fracturing oil pressure and casing pressure are predicted according to the construction string of Well G83-44, and the results are shown in the table below.

Table 1. Ground pressure prediction of construction.

\begin{tabular}{|l|l|l|l|}
\hline Displacement(m $3 / \mathrm{min})$ & 2.2 & 2.5 & 2.8 \\
\hline Export flow velocity(m/s) & 221.6 & 236.4 & 251.1 \\
\hline Nozzle pressure drop(MPa) & 32.7 & 37.2 & 42.0 \\
\hline Pipe string friction(MPa) & $7.9-9.2$ & $\begin{array}{l}8.8- \\
10.3\end{array}$ & $\begin{array}{l}9.8- \\
11.4\end{array}$ \\
\hline Annulus friction(MPa) & $19.8-$ & $22.3-$ & $\begin{array}{l}25.0- \\
29.1\end{array}$ \\
\hline $\begin{array}{l}\text { Estimated perforation oil } \\
\text { pressure(MPa) }\end{array}$ & $\begin{array}{l}60.4- \\
65.1\end{array}$ & $\begin{array}{l}68.3- \\
73.5\end{array}$ & $\begin{array}{l}76.7- \\
82.5\end{array}$ \\
\hline $\begin{array}{l}\text { Annular flow rate during } \\
\text { fracturing(m } 3 \text { min) }\end{array}$ & 1.0 & 1.0 & 1.0 \\
\hline $\begin{array}{l}\text { Annular friction during } \\
\text { fracturing(MPa) }\end{array}$ & $2.7-3.1$ & $2.7-3.1$ & $\begin{array}{l}2.7- \\
3.1\end{array}$ \\
\hline $\begin{array}{l}\text { Estimated sleeve pressure } \\
\text { during fracturing(MPa) }\end{array}$ & $\begin{array}{l}26.3- \\
26.8\end{array}$ & $\begin{array}{l}26.3- \\
26.8\end{array}$ & $\begin{array}{l}26.3- \\
26.8\end{array}$ \\
\hline $\begin{array}{l}\text { Estimate the oil pressure } \\
\text { during fracturing(MPa) }\end{array}$ & $\begin{array}{l}48.4- \\
49.5\end{array}$ & $\begin{array}{l}53.8- \\
55.0\end{array}$ & $\begin{array}{l}59.6- \\
61.0\end{array}$ \\
\hline
\end{tabular}

According to the calculation results, in order to ensure the smooth completion of the construction, the total displacement is guaranteed to be $3.5 \mathrm{~m}^{3} / \mathrm{min}$, including $2.5 \mathrm{~m}^{3} / \mathrm{min}$ tubing displacement and $1.0 \mathrm{~m}^{3} / \mathrm{min}$ casing displacement. The construction oil pressure limit is $80 \mathrm{MPa}$, and the casing pressure limit is $35 \mathrm{MPa}$. At the same time, casing pressure and hydrostatic column pressure were used to control the formation initiation pressure lower than the current formation ${ }^{[8]}$. Ensure stable displacement of tubing and annulus during construction.

\subsection{Fracturing string strength check}

\subsubsection{Stress analysis of hydraulic jet fracturing string}

It is mainly subjected to the action of axial tension. The composition of axial tension varies in different stages of fracturing. Specific stress conditions are as follows.

(1) Before hydraulic jet fracturing, the string is mainly subject to buoyancy and gravity. At this stage, there is fracturing liquid base fluid in the tubing with small fluid density and large buoyancy coefficient.

(2) In the hydraulic jet perforating stage, the string is mainly affected by buoyancy, gravity, internal pressure and fluid viscous friction. At this stage, the fluid is a perforating fluid mixed with quartz sand, and the relative density of the base liquid phase is higher than that of the previous stage, and the sum of gravity and buoyancy force is less than that before fracturing.

(3) In the hydraulic jet fracturing stage, the string forces are also buoyancy, gravity, internal pressure and fluid viscous friction. The difference is that both tubing and annulus have downward friction. At this point, there is a sand-carrying fluid mixed with ceramsite in the string, and the ratio of density to the perforated liquid phase increases again, resulting in a smaller sum of buoyancy and gravity.

\subsubsection{Construction of the string}

From the bottom up: Guide head $0.14 \mathrm{~m}+$ porous pipe $0.42 \mathrm{~m}+$ one-way valve (through hole diameter $22 \mathrm{~mm}$, ball $25 \mathrm{~mm}$ ) + first cluster spray gun (no sliding sleeve, inner diameter $50 \mathrm{~mm}$, spray gun center position $3078 \mathrm{~m}$ ) $+2-7 / 8$ "N80 thickened tubing + second cluster spray gun (no sliding sleeve, inner diameter $50 \mathrm{~mm}$, The center of the spray gun is $3039 \mathrm{~m})+2-7 / 8$ "N80 thickened tubing ( 2 pieces $)+$ safety joint $+2-7 / 8$ " N80 thickened tubing $(2$ pieces) + depth adjustment sub +2000m 2-7/8 "N80

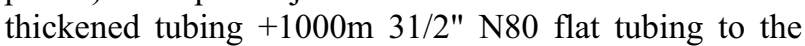
wellhead.

\subsection{Pump injection program}

According to the characteristics of G83-44 well and the calculation results of previous parameters, the pumping

\begin{tabular}{|c|c|c|c|c|c|c|}
\hline \multirow[b]{2}{*}{ Steps } & \multicolumn{2}{|c|}{ tubing } & \multicolumn{2}{|c|}{ casing } & \multirow[b]{2}{*}{$\begin{array}{c}\text { Sand } \\
\text { than( } \\
\%)\end{array}$} & \multirow{2}{*}{$\begin{array}{c}\text { Amou } \\
\text { nt of } \\
\text { sand }( \\
\left.\mathrm{m}^{3}\right)\end{array}$} \\
\hline & $\begin{array}{c}\text { Liquid } \\
\text { measure } \\
\left(\mathrm{m}^{3}\right)\end{array}$ & $\begin{array}{c}\text { Displace } \\
\operatorname{ment}^{\left(\mathrm{m}^{3}\right.} \\
/ \mathrm{min})\end{array}$ & $\begin{array}{c}\text { Liquid } \\
\text { measur } \\
\mathrm{e}\left(\mathrm{m}^{3}\right)\end{array}$ & $\begin{array}{l}\text { Displac } \\
\text { ement( } \\
\left.\mathrm{m}^{3} / \mathrm{min}\right)\end{array}$ & & \\
\hline
\end{tabular}
program was prepared.

Table 2. Pumping procedures for fracturing operations. 


\begin{tabular}{|l|c|c|c|c|c|c|}
\hline $\begin{array}{l}\text { Perforatin } \\
\text { g fluid }\end{array}$ & 28.6 & 2.5 & $/$ & $/$ & 7.0 & 2.0 \\
\hline $\begin{array}{l}\text { Displacem } \\
\text { ent fluid }\end{array}$ & 29.3 & 2.5 & $/$ & $/$ & $/$ & $/$ \\
\hline $\begin{array}{l}\text { Displacem } \\
\text { ent fluid }\end{array}$ & 2.0 & 2.5 & $/$ & $/$ & $/$ & $/$ \\
\hline $\begin{array}{l}\text { Prepad } \\
\text { fluid }\end{array}$ & 20.0 & 2.0 & 10 & 1.0 & $/$ & $/$ \\
\hline $\begin{array}{l}\text { Carrying } \\
\text { fluid }\end{array}$ & 16.0 & 2.0 & 8 & 1.0 & 6 & 1.0 \\
\hline $\begin{array}{l}\text { Prepad } \\
\text { fluid }\end{array}$ & 20.0 & 2.0 & 10 & 1.0 & $/$ & $/$ \\
\hline $\begin{array}{l}\text { Carrying } \\
\text { fluid }\end{array}$ & 15.0 & 2.0 & 7.5 & 1.0 & 7 & 1.1 \\
\hline $\begin{array}{l}\text { Prepad } \\
\text { fluid }\end{array}$ & 40.0 & 2.0 & 20 & 1.0 & $/$ & $/$ \\
\hline $\begin{array}{l}\text { Carrying } \\
\text { fluid }\end{array}$ & 8.0 & 2.0 & 4 & 1.0 & 8 & 0.6 \\
\hline $\begin{array}{l}\text { Carrying } \\
\text { fluid }\end{array}$ & 10.0 & 2.0 & 5 & 1.0 & 14 & 1.4 \\
\hline $\begin{array}{l}\text { Carrying } \\
\text { fluid }\end{array}$ & 12.0 & 2.0 & 6 & 1.0 & 20 & 2.4 \\
\hline $\begin{array}{l}\text { Carrying } \\
\text { fluid }\end{array}$ & 14.0 & 2.0 & 7 & 1.0 & 26 & 3.6 \\
\hline $\begin{array}{l}\text { Carrying } \\
\text { fluid }\end{array}$ & 14.0 & 2.0 & 7 & 1.0 & 26 & 3.6 \\
\hline $\begin{array}{l}\text { Carrying } \\
\text { fluid }\end{array}$ & 10 & 2.0 & 5 & 1.0 & 30 & 3 \\
\hline $\begin{array}{l}\text { Carrying } \\
\text { fluid }\end{array}$ & 8 & 2.0 & 4 & 1.0 & 34 & 2.7 \\
\hline $\begin{array}{l}\text { Carrying } \\
\text { fluid }\end{array}$ & 6 & 2.0 & 3 & 1 & 37 & 2.2 \\
\hline $\begin{array}{l}\text { Carrying } \\
\text { fluid }\end{array}$ & 4 & 2.0 & 2 & 1.0 & 40 & 1.6 \\
\hline $\begin{array}{l}\text { Displacem } \\
\text { ent fluid }\end{array}$ & 12 & 2.0 & 6.0 & 1.0 & $/$ & $/$ \\
\hline $\begin{array}{l}\text { Total } \\
\text { flu }\end{array}$ & 268.9 & $/$ & 104.5 & $/$ & $/$ & 25.2 \\
\hline
\end{tabular}

accumulated oil of an average of $2500 t$ per well, and the average water cut of a single well decreases by 8.5 percentage points, achieving the purpose of oil increasing and water controlling.

\section{Conclusions and Suggestions}

(1) The hydraulic jet precise fracturing technology can control the fracture initiation point and form fractures in the specified position. For oil Wells with water layers above and below the fracturing target layer, it can avoid pressing the boiling water layer, realize precise directional fracturing, improve the fracturing effect and realize the purpose of water control and oil increase.

(2) The successful application of 4 Wells in W27 Oilfield has confirmed the feasibility of hydraulic injection precision fracturing technology in multi-layer heterogeneous and low permeability reservoir for water control and oil increase. In the next step, we will continue to deepen the research, continue to improve the fracturing process, optimize the construction parameters, and popularize the hydraulic injection precision fracturing technology to similar reservoirs and similar Wells, so as to realize the benefit and potential exploitation of old oil fields.

\section{References}

1. Zhang Gaoqun et al. Research and application of hydraulic injection and sand fracturing technology in Zhongyuan oilfield [J]. Drilling \& Production Technology, 2010,33(5) : 65-66, 71.

2. Eberhard M J,Surjaatmadia J,Peterson E M, etal. Precise fracture initiation using dynamic fluid movement allows effective fracture development in deviated well bores[R].SPE 62889,2000.

3. Tian Shousheng, Li Gensheng, Huang Zhongwei, et al. Research progress of hydraulic jet fracturing mechanism and technology [J]. Oil Drilling \& Production Technology, 2008,30(1):58-62.

After the potential analysis and feasibility demonstration of the system, 4 Wells were selected from W27 oilfield to implement hydraulic injection precise fracturing technology. Through scientific optimization of fracturing operation parameters, the four Wells were operated smoothly, with a total of $1606.3 \mathrm{~m}^{3}$ of fracturing fluid and $101.8 \mathrm{~m}^{3}$ of proppant injected.

Table 3. Fracturing parameters of 4 Wells in W27 Oilfield.

\begin{tabular}{|l|l|l|l|l|}
\hline Well & G83-44 & G80-46 & G78-52 & G82-44-1 \\
\hline $\begin{array}{l}\text { The injection } \\
\text { point }\end{array}$ & $\begin{array}{l}3039 \mathrm{~m}, \\
3078 \mathrm{~m}\end{array}$ & $\begin{array}{l}2995 \mathrm{~m}, \\
3018 \mathrm{~m}\end{array}$ & $2964 \mathrm{~m}$ & $3057 \mathrm{~m}$ \\
\hline Amount of liquid & 372 & 551.3 & 347.5 & 335.5 \\
\hline Amount of sand & 25.2 & 27.8 & 24.4 & 24.4 \\
\hline Displacement & 3 & 3.5 & 4.0 & 4.0 \\
\hline
\end{tabular}

\subsection{The fracturing effect}

After the implementation of 4 Wells in W27 oil field, the accumulated oil of $10018 \mathrm{t}$ is increased by an average of $6.0 \mathrm{t} / \mathrm{d}$ in the initial stage of a single well, the

4. Li Gensheng, Niu Jilei, et al. Experimental Study on Hydraulic Sandblasting Perforation Mechanism [J]. Journal of the University of Petroleum (Natural Science),2002,26 (2) : 31-34.

5. Xia Qiang, Huang Zhongwei, Li Gensheng, et al. Experimental Study on Jet Pressure Regulation in Hydraulic Jetting Hole [J]. Fluid mechanics,2009,37 (2) : $1-5$.

6. SURJAATMADJA J B . Subterranean formation fracturing methods $[\mathrm{P}]$. U. S. Patent No. 5765, 1998

7. SURJAATMADJA J B, GRUNDMANN S R, et a1. Hydra jet fracturing: an effective method for placing many fractures in open hole horizontal wells[R]. SPE 48 856, 1998

8. Li Gensheng, Xia Qiang et al. Feasibility analysis and design calculation of hydraulic jet fracturing in 
deep well [J]. Oil drilling technology,2011,39 (5) : 58-62. 